\title{
Recent developments in gluten-free bread baking approaches: a review
}

\author{
Kun WANG ${ }^{1}$, Fei LU ${ }^{1}$, Zhe $\mathrm{LI}^{1}$, Lichun $\mathrm{ZHAO}^{1}$, Chunyang HAN ${ }^{2}$
}

\begin{abstract}
Celiac disease (CD) is one of the most common human intestinal malabsorption diseases. The only effective treatment for patients with CD is to follow a gluten-free (GF) diet strictly. Nowadays, the increasing incidence of CD promotes worldwide interests for various desirable GF products. However, baking without gluten, the key ingredient for bread structure and quality, is a big challenge for all bakers and cereal researchers. Several approaches have been applied to understand and improve gluten-free bread (GFB) elaboration and further studies are still required. The main focus of this review is to discuss the approaches for GFB improvements in recent 5 years, including the use of novel alternative flours, functional ingredients, processing aids, additives, innovative techniques, and their combinations.
\end{abstract}

Keywords: celiac disease; gluten-free bread; process; quality.

Practical Application: Know celiac disease and developments of gluten-free bread.

\section{Introduction}

Celiac disease (CD) is a chronic intestinal malabsorption disease characterized by life-long intolerance to materials such as prolamins in wheat (gliadin), barley (hordein), rye (secalin), and possibly oats (avidins), due to genetic factors (Murray, 1999). Celiac disease causes immunologically mediated inflammatory injury of the small intestinal mucosa, which leads to malabsorption of nutrients and gastrointestinal disorders (Kagnoff, 2005). Currently, studies have shown that the disease affects approximately $1 \%$ of the world population (Catassi \& Fasano, 2008; Mustalahti et al., 2010). The only current remedy is a life-long total exclusion of gluten and other related proteins from the diet. The European Union imposes a regulation stating that GF foods which are consisted of naturally GF ingredients should contain less than $20 \mathrm{ppm}$ gluten (i.e., $10 \mathrm{ppm}$ gliadin or $1 \mathrm{mg}$ gliadin per $100 \mathrm{~g}$ ) (Thompson, 2001). However, dough produced in the absence of gluten presents poor rheological properties, affecting the final quality. Gluten is a protein complex capable of retaining carbon dioxide, and it confers unique properties to yeast-leavened baked goods. Gluten is composed of two main groups of protein fractions: gliadins, which ensure the viscosity of the dough, and glutenins, responsible for dough elasticity (Becker et al., 2007). Baking without gluten is a technological challenge, owing to GF flours' inability to form cohesive and elastic doughs. Additionally, the unique characteristics of wheat gluten makes it hard to find raw materials, additives, or ingredients that can entirely replace it and at present, many GF products available in the market have low nutritional properties, poor taste, and inferior quality (Pszczola, 2012). In the past few years, the use of alternative ingredients including starches (Tsatsaragkou et al., 2014), GF flours (Lemos et al., 2012; Wronkowska et al., 2013), hydrocolloids
(Sabanis \& Tzia, 2011; Nicolae et al., 2016), proteins (Ziobro et al., 2016), enzymes (Yano, 2012; Palabiyik et al., 2016), and emulsifiers (López-Tenorio et al., 2015), is allowing an improvement in dough rheological characteristics. More recently, novel processing technologies such as gluten proteolysis and sourdough fermentation (Stefańska et al., 2016; Różyło et al., 2016), freezing and partial baking technologies (Mezaize and othera 2010, Sciarini et al., 2012), and low-gliadin wheat breeding (Barro et al., 2016) have proved to be promising alternative techniques to enhance gluten-free bread (GFB) quality. These innovative technologies provide solutions towards the improvement of GF dough and products.

This review focuses on the recent approaches undertaken in GF baking and presents alternative grains and starches, innovative techniques, new additives, as well as combined uses of these elements towards the improvement of GF products.

\section{Alternative gluten-free flours and starches}

Over the past decade, various products have been used to replace gluten, including cassava, potato, or rice starches, cereals like maize, rice or sorghum flours, and other innovative functional materials such as pseudocereals, legume, seeds, nuts and fruit-based ingredients, as described in Table 1.

Starches, play an important role in bread baking processes. During bread baking, starch granules gelatinize and have the ability to trap air bubbles, facilitating gas retention during fermentation (Hug-Iten et al., 2001). Rice and maize flours, along with various techniques or additives have also been applied to improve physicochemical properties, acceptance, and shelf life of dough and bread (Therdthai et al., 2016; Hager et al., 2012b). 
Table 1. Summary of alternative materials for gluten-free bread improvement.

\begin{tabular}{|c|c|c|c|}
\hline GF materials & Additional ingredient/flour treatment & Results & References \\
\hline \multicolumn{4}{|l|}{ Cereal flours } \\
\hline Sorghum & Cassava, maize, potato or rice starch & $\begin{array}{l}\text { Decreased crumb firmness, chewiness } \\
\text { Increased cohesiveness, springiness, resilience }\end{array}$ & (Onyango et al., 2011) \\
\hline Teff & & Low specific volume & (Hager et al., 2012a) \\
\hline \multicolumn{4}{|l|}{ Pseudocereals } \\
\hline Quinoa & & $\begin{array}{l}\text { Presented similar bake loss } \% \text {, specific volume, protein } \\
\text { content to control }\end{array}$ & (Turkut et al., 2016) \\
\hline Buckwheat & & Increased loaf specific volume, color, crumb softness & (Wronkowska et al., 2013) \\
\hline \multicolumn{4}{|l|}{ Legumes } \\
\hline Chickpea & & High specific volume, softness & (Miñarro et al., 2012) \\
\hline Blackcurrant seed & Defatted & Increased loaf volume, nutritions, softness & (Korus et al., 2012) \\
\hline Strawberry seed & Defatted & Increased loaf volume, sensory acceptance, nutritions & \\
\hline \multicolumn{4}{|c|}{ 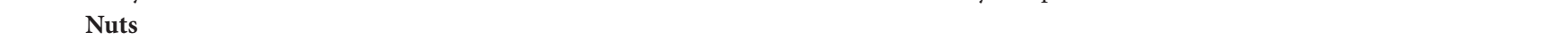 } \\
\hline Tiger nut milk & & $\begin{array}{l}\text { Increased specific volume, crumb softness, sensory } \\
\text { characteristics }\end{array}$ & (Aguilar et al., 2015) \\
\hline $\begin{array}{l}\text { Tiger nut milk } \\
\text { by-product }\end{array}$ & & Impaired bread quality & \\
\hline Tiger nut flour & & Bread characteristics similar to controls & \\
\hline Acorn & Pectin and guar gum & $\begin{array}{l}\text { Increased volume, sensory acceptance, nutritional values } \\
\text { Slower staling }\end{array}$ & (Korus et al., 2015) \\
\hline \multicolumn{4}{|c|}{ 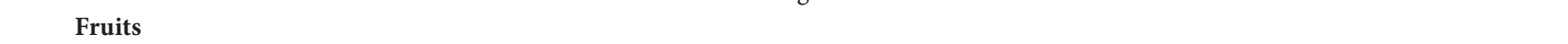 } \\
\hline
\end{tabular}

Sorghum has been used in formulations to diversify GF bakery products and Onyango et al. (2011) have reported promising results with starch-based (corn, potato, rice, or cassava starches) formulation that was made of up to $70 \%$ sorghum. Alternative cereal ingredients such as millet and teff exhibited promising properties in GF formulation that could improve the quality of GF goods. Dough and bread formulated with millet flour presented low specific volume and high bread hardness compared to the control (Sayed et al., 2016). Teff holds excellent nutritional qualities, however, bread prepared with 100\% teff flour showed a dense structure and low specific volume (Hager et al., 2012a). Technology approaches such as hydrocolloids (Hager \& Arendt, 2013) or sourdoughs additions (Campo et al., 2016) provide a way to improve these defects.

Quinoa and amaranth contain higher proportions of soluble dietary fibers (DFs) than cereals, with high contents of pectic substances and xyloglucans, respectively, providing a good functional substitute for gluten (Lamothe et al., 2015). Replacement of starch with whole amaranth flour (Lemos et al., 2012) and buckwheat flour (Wronkowska et al., 2013) not solely improved the nutritional value of GFB, but also yielded desirable final quality. Turkut et al. (2016) replaced buckwheat flour with increasing levels of quinoa flour and observed an increasing dough viscosity due to higher amount of soluble dietary fiber content compared to buckwheat flour, which would compensate the structure loss associated to absence of gluten. Miñarro et al. (2012) investigated the characteristics of four GF formulations made with chickpea flour, pea protein isolate (PPI), soya flour, and carob germ flour to evaluate a potential substitution of soya protein by other legume proteins. Carob germ flour bread showed the lowest specific volume value $\left(2.51 \mathrm{~cm}^{3} / \mathrm{g}\right)$, even though it displayed good batter rheological properties. The results also showed that bread produced with chickpea flour yielded good results for all the parameters studied, indicating that it could possibly substitute soya flour.

Interesting results have been achieved by incorporating seeds, nuts and acorn flour.

According to Steffolani et al. (2014), bread containing 15\% chia flour showed lower specific volume and increased hardness. However, 
these effects were attenuated when the chia was incorporated as a seed. Moreover, chia flour addition generated a darker crust and crumb, less appreciated by consumers than breads produced with chia seeds. Korus et al. (2012) reported that the incorporation of defatted strawberry (DS-ST) significantly increased the loaf volume while defatted blackcurrant (DS-BC)-containing breads generated opposite results.

Chestnut flour was tested as a potential viable flour in GFB. Recently, spontaneously fermented chestnut flour sourdoughs have been demonstrated efficient on improvement of bread specific volume and crumb hardness (Aguilar et al., 2016). Aguilar et al. (2015) incorporated different tiger nut-derived products (tiger nut milk, tiger nut milk byproduct, tiger nut flour) into a corn starch-based GFB formulation to substitute the allergenic soya flour. Physicochemical properties of bread showed that the quality of bread formulations elaborated with these three derivants followed the order of tiger nut milk $>$ tiger nut flour $>$ tiger nut milk byprduct. Korus et al. (2015) included different proportions of debittered acorn flour into a starch-based bread recipe, along with pectin and guar gum. Promising results showed higher volume, slower staling and better crumb characteristics as well as good sensory acceptance. Addition of limited amounts of acorn flour not only strengthened dough structure but also enriched bread with proteins, minerals, and DFs.

Considering the nutritional importance of fruits, ingredients such as unripe banana (Sarawong et al., 2014) and orange pomace (O'Shea et al., 2015) have been tested in GFBs. Recently, Rocha Parra et al. (2015a, 2015b) developed an apple pomace-enriched formulation of GF baked product along with cassava starch and rice flour. The authors optimized the level of apple pomace and water and explained the interaction between apple pomace and starch from a microstructural point of view.

\section{Approaches for improvements of dough and bread}

Usually, patients with CD must follow a strict GF diet, typically involving a lower nutrition intake than that taken by healthy individuals. Owing to the lack of gluten, which can hold water but also form the matrix to embed the starch, GFBs commonly have poor structure and quality (Zannini et al., 2012). A range of additives has been studied to solve this issue.

\subsection{Nutritional and functional ingredients}

DFs have been widely studied for their nutritional and functional benefits in GFB formulations, owing to their water binding capacity, gel forming ability, fat mimetic properties, and textural and thickening effects (Tsatsaragkou et al., 2016). Studies have been performed on the effects of insoluble fibers on texture and sensory acceptability of GFB and the length or partical size also do contributions (Martínez et al., 2014). Dough cohesion and starch pasting properties were also influenced by fiber addition (pea fiber, oat bran) (Aprodu \& Banu, 2015), owing to their high water-binding capacity to imparting dough viscosity and starch gelatinization for bread making (Capriles \& Arêas, 2014).
Soluble fiber and resistant starch (RS) enrichment can decrease the glycemic response of GFB, which is highly desirable for individuals with concomitant $\mathrm{CD}$ and insulin-dependent diabetes. Formulations with functional soluble fibers such as $\beta$-glucan and psyllium have been studied intensively as a way to assist gut regulation and lower serum LDL cholesterol concentrations (Gunness \& Gidley, 2010.)

Prebiotics such as inulin, oligofructose, and RS are the most widely researched functional DFs for GFB production. According to Capriles \& Arêas (2013), GFB with increasing levels $(4 \%, 8 \%, 10 \%$, and $12 \%)$ of inulin-type fructans (ITFs) showed higher specific volume below $10 \%$, while observing a decline above $10 \%$. The authors suggested that ITFs can form a gel structure and retain $\mathrm{CO}_{2}$ in the same way as some hydrocolloids. Different degrees of polymerization (DP) of inulin also affect the quality of the bread. Generally, lower DP of of inulin has stronger effects than elevated ones (Ziobro et al., 2013). RS plays many functional roles and can not only reduce the energy of food and and enhance digestive functions but also improve bread quality (Witczak et al., 2016). In addition, RS caused no increase in crumb firmness but improved its elasticity and porosity (Tsatsaragkou et al., 2014).

\subsection{Additives in gluten-free bread making}

Additives such as hydrocolloids, proteins and enzymes (Table 2) have also been applied in GF bread making with the intention of improving the rheological properties and final quality of bread.

Hydrocolloids are often used as a thickening agent, binding water and increasing dough viscosity, for better volume, texture, and final quality of bread (Mir et al., 2016). HPMC and xanthan gum (XG) are the most widely used hydrocolloids in GF formulation due to their capacity to improve the quality of the products (Hager \& Arendt, 2013). Other hydrocolloids such as guar gum, CMC, locus bean gum and agarose are also used in GF doughs. Recently, other hydrocolloids like cress see gum (Naji-Tabasi \& Mohebbi, 2015) and sodium carboxymethyl cellulose (NaCMC) (Nicolae et al., 2016) have been used as novel gluten substitutes which obtained promising final bread quality.

The incorporation of protein-based ingredients from different sources like legumes, egg, and dairy in GF doughs has been a promising topic. Details about the proteins from these sources were shown in Table 2. Addition of proteins can not only enhance the functional and nutritional properties of GF products but also improve sensory quality by increasing Maillard browning and flavor (Deora et al., 2015). Ziobro et al. (2016) checked the effects of selected protein isolates (albumin, collagen, pea, lupine, and soy) and concentrates on the structure and quality of GFB without the introduction of any other structure forming additives such as guar gum and pectin. They found that replacing gums with proteins generated changes in crumb structure and yielded a darker bread. Formulations deprived of plant gums allowed to produce breads with the required quality parameters, low in or even free of structure-forming agents but enriched in amino acids. 
Table 2. Additions used in gluten-free formulations.

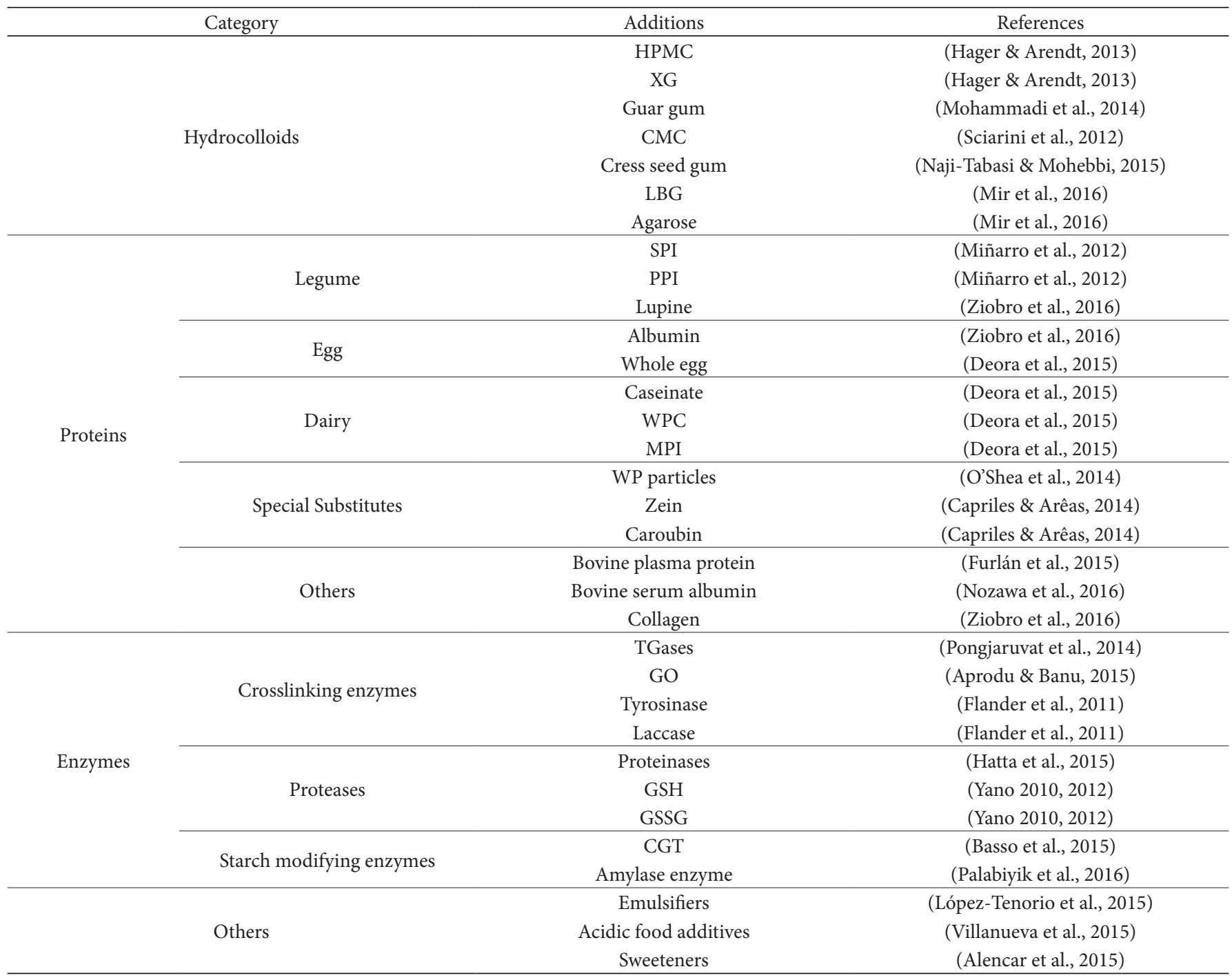

HPMC: hydroxypropyl methylcellulose; CMC: carboxymethylcellulose; XG: xanthan gum; LBG: Locus bean gum; SPI: soy protein isolate; PPI: pea protein isolate; WPC: whey protein concentrate; MPI: milk protein isolate; TGase: transglutaminase; GO: glucose oxidase; GSH: reduced glutathione; GSSG: oxidized glutathione; CGT: cyclodextrin glycosyltransferase.

Another novel protein, bovine plasma proteins, has been incorporated into GF formulations with different process [by ultrafiltration and freeze-drying operations (PUF), with the addition of sucrose (PUFS), or inulin (PUFI)]. All the breads showed improvements in rheological properties and related product attributes (Furlán et al., 2015). However, incorporation of bovine serum albumin into rice based dough, along with soymilk, inhibited the fermentation and generated bread with crust hollowing (Nozawa et al., 2016).

Special promising protein including whey protein particles at the mesoscopic scale, zein and caroubin provided novel substitutes for preparation of GFB. Details about these studies have been reported by the review of O'Shea et al. (2014).

Enzymatic approaches are often used to enhance the GF dough-handling properties and to improve the final quality and shelf life of breads. Starch-modifying enzymes [amylase and cyclodextrin glycosyltransferase (CGT)] and protein modifying enzymes (crosslinking enzymes and proteases) are often added in GFB formulations (Renzetti \& Rosell, 2016).

Crosslinking enzymes including transglutaminase (TG, EC 2.3.2.13), glucose oxidase (GO, EC1.1.3.4), tyrosinase (EC 1.14.18.1) and laccase (EC 1.10.3.1) have been prevalently used for the development of GFBs.

According to Pongjaruvat et al. (2014), the volume of rice bread containing $0.1 \%$ TG was more competitive than the one obtained with the wheat control. Conversely, increasing TG concentrations generated a deteriorating effect on bread volume and increased crumb hardness and chewiness. Bread prepared with microbial TG $(1 \mathrm{U} / \mathrm{g})$ and guar gum $(30 \mathrm{~g} / \mathrm{kg})$ possessed desirable quality (Mohammadi et al., 2015). Aprodu \& Banu (2015) added GO at $0.1 \%$ to a fiber-enriched GF dough and observed an increase in starch gelatinization accompanied by a decrease 
in starch retrogradation values. There are few studies on laccase and tyrosinase applications in GF formulations. Flander et al. (2011) reported high specific volume and increased crumb softness of oat bread combining Trichoderma reesei tyrosinase and xylanase. While the combination of Trametes hirsute laccase and xylanase also improved the specific volume of the bread, crumb softness remained unaltered.

Proteases (EC 3.4), including proteinases and peptidases, are enzymes that can hydrolyze the peptide bonds present in proteins. Recently, Hatta et al. (2015) reported that the degradation of $\alpha$ - and $\beta$-glutelin subunits of rice protein is essential for the improvement of bread texture and quality. They observed improvements in the gas holding and textural properties in protease-treated (metallo, serine, cysteine proteases) rice breads, which almost completely degraded the $\alpha$ - and $\beta$-glutelin subunits. In contrast, degradation of rice glutelins or these improvements were not observed in the rice batter treated with aspartyl proteases.

Glutathione can also degrade the disulphide linkages between $\alpha$ - and $\beta$ - subunits of rice glutelins (Yano, 2010, 2012). Bread incorporated with reduced glutathione (GSH) and oxidized glutathione (GSSG) in rice batter showed similar structure to wheat bread but with a smoother appearance (Yano, 2010, 2012). Moreover, sensory analysis revealed that GSSG bread had a significantly reduced sulfurous odor campared with GSH bread (Yano, 2012).

In a recent study, Basso et al., (2015) observed that breads containing CGT (EC 2.4.1.19) produced by Bacillus firmus strain 37 achieved higher specific volumes, better crumb textures, and higher sensory scores than those prepared with commercial CGT. Palabiyik et al. (2016) reported that fungal amylase clearly affected its starch substrate's properties, while the other enzymes, whose substrates were fiber and protein molecules did not generate any effects. The results obtained from this study highlighted the potential usage of fungal amylase in various food products as a mean to alter their pasting and textural properties.

Other additives such as emulsifiers (López-Tenorio et al., 2015), acidic food additives (Villanueva et al., 2015) and sweeteners (Alencar et al., 2015) have been used to improve the quality of GF dough and bread.

\section{Technological approaches}

Recently, novel processing techniques including gluten proteolysis, genetically modified wheat breeding, sourdough fermentation, frozen storage, and partial baking have been applied, either individually or in conjunction, to obtain better quality characteristics of GF products.

\subsection{Gluten proteolysis and Sourdough fermentation}

A relatively new trend is the utilization of proteolytic enzyme to detoxify gluten by cleaving the peptide bonds next to proline- and glutamine-residues, with the action of prolyl-endopeptidases (PEPs). Unlike human gastrointestinal protease, PEPs can degrade gluten to amino acids or nontoxic peptides (less than nine amino acid residues) (Heredia-Sandoval et al., 2016). In addition, cereal germination can also degrade immunostimulatory gluten peptides and thereby diminish its toxic effects. Wheat grains hydrolyzed at certain conditions $\left(20^{\circ} \mathrm{C}, \mathrm{pH} 5.5\right)$ showed the lowest concentration of glutens at the seventh day of germination (Michalcová et al., 2012).

Lactic acid bacteria (lactobacilli) (LAB) are known to possess a complex protease system, which can hydrolyse various proline residues of gluten. Selecting strains of LAB with targeted proteolytic effects, due to the complexity of the gliadin locus with multiple expressed genes, is vital important. Recently, Stefańska et al. (2016) selected $11 \mathrm{LAB}$ strains capable of hydrolyzing albumin/globulin and gliadin in bakery sourdoughs. However, the concentration of polypeptides with IgE-reactive epitopes remains high and therefore formulas with the combination of fungal proteases and lactobacilli were developed, providing a new tool to eliminate gluten toxicity. Bread prepared with flours used selected sourdough $\mathrm{LAB}$ and fungal proteases presented similar physicochemical properties to control (Rizzello et al., 2014).

The application of sourdough may upgrade the characteristics of breads like texture, flavor, nutritional value and shelf-life due to the metabolites produced by LAB (De Vuyst \& Vancanneyt, 2007). These positive contributions could be exploited for the preparation of high quality GFBs with various GF flours.

Dried sourdough comes in powder forms, which presents some advantages over fresh sourdough, including a shorter fermentation time and longer sourdough shelf life (Różyło et al., 2015a). Recently, freeze-dried sourdough has also been used in GF formulation to improve the quality of final breads (Różyło et al., 2015a; Różyło et al., 2015b; Różyło et al., 2016). The authors investigated the effects of added fresh and freeze-dried amaranth, buckwheat and rice sourdoughs at different ratios during GFB production. They concluded that sourdoughs dried at $40^{\circ} \mathrm{C}$ were the most suitable for GFB production. $20 \%$ and $30 \%$ additions of freeze-dried buckwheat sourdoughs conferred the best baking performances, while amaranth could only be added up to a $10 \%$ ratio. Moreover, rice sourdough at $10 \%$ or $20 \%$ ratios proved to be a good substitute for fresh sourdough.

\subsection{Genetically modified wheat breeding}

Currently, the application of RNA interference (RNAi) technology to down-regulate-coeliac-toxic gliadins and/or glutenins attracts more interests for researchers. RNAi is a reverse genetics tool, producing double-stranded RNA that makes gene silencing before forming gluten (Watanabe, 2011).

Becker et al. (2007) reported down-regulation of $\alpha$-gliadins by utilization of RNAi and produced a variety of transgenic lines with the a-gliadins silenced. Compared to the wild type flour, results of reversed-phase high-performance liquid chromatography (RP-HPLC) showed that content of a-gliadins in transgenic flour was reduced by over $60 \%$ (Becker et al., 2012). Whereas the overall contents of gliadins were reduced by $9 \%$ for the compensatory increases in other storage proteins like albumins/globulins, $\omega$-gliadins, $\gamma$-gliadins and high-molecular-weight glutenin subunits (HMW-GS) with exception of low-molecular-weight glutenin subunits (LMW-GS). Gluten of the transgenic is stronger which was probably associated with the decreasing ratio of the gliadin to glutenin resulting from the reduction in a-gliadins. 
While the rheological properties of the two lines were similar. RNAi has also been applied to produce transgenic lines with reduced levels of $\omega-5$ gliadins which were good for wheatdependent exercise-induced anaphylaxis (Altenbach et al., 2014).

More studies about the down-regulation of only $\gamma$-gliadins (Pistón et al., 2011), all gliadins ( $\alpha-, \omega$ - and $\gamma-$ ) (Gil-Humanes et al., 2010), and all gliadins and LMW-GS (Gil-Humanes et al., 2011) in wheat have been reported by the group of Francisco Barro. Bread prepared with low-gliadin flour presented higher lysine content and final bread quality, similar to normal bread. Whereas bread volume showed a reduction between about $20 \%$ and $30 \%$ compared to control (Gil-Humanes et al., 2014). Details about these investigations can be found in the review of Rosell et al. (2014). Recently, Barro et al. (2016) reported that seven plasmid combinations, encompassing RNAi fragments from $\alpha-, \gamma-, \omega$-gliadins, and LMW-GS, could down-regulate prolamin effectively. Compared to the wild type, gluten content in two of the plasmid combinations was reduced by over $90 \%$ (93\%, 92\% for Plasmid Combinations 5, 7 respectively); three plasmid combinations were totally devoid of immunogenic epitopes from $\omega$ - and $\gamma$-gliadins. These lines could probably be useful for cultivating coeliac-safe wheat. However, the resistance to transgenic foods in some country and the insufficiency of clinical trials in $\mathrm{CD}$ patients as such limit the commercialisation of the low-gliadin wheat.

\subsection{Frozen and partial baking technologies}

Frozen dough is a promising alternative to conventional bread making, inserting a freezing process at different steps of the bread making process. It is a value-added product that improves fresh bread availability. Moreover, patients with CDs can prepare and consume it at home when needed. Frozen dough breads displayed lower specific volumes due to the decrease in yeast sensitiveness and the change in the structure of the GF dough. Additionally, the crumbs were harder and the crust color characteristics were modified (Mezaize et al., 2010).

In recent years, the market has been rapidly moving from frozen dough to partially baked bread (part-baked, par baked bread or pre-baked bread). Partially baked bread is a semi-finished product with proper crumb texture and minimum crust coloration. The part-baking process consists of two stages: an initial baking stage until the bread structure is fixed followed by storage, and a second baking stage to create an appropriate flavor and crust color (Najafabadi et al., 2014). Sciarini et al. (2012) assessed the impact of the partial baking process on GFB and studied how $\mathrm{CMC}$ and $\mathrm{XG}$ incorporation affected this process. Part-baked breads displayed lower specific volumes, denser crumb appearances, and higher crumb hardness. The addition of hydrocolloids, in particular CMC, partially mitigated these negative effects.

Other novel technologies such as pregelatinized treatment (Pongjaruvat et al., 2014), extrusion technology (Clerici et al., 2009), high-pressure processing (Vallons et al., 2011) and microwave baking (Therdthai et al., 2016) have also been investigated to improve the texture and quality of GF dough and bread.

\section{Conclusions}

In response to a worldwide increasing prevalence of celiac disease in adults, the need to offer celiac disease patients satisfactory quality and wide variety of GF baking foodstuffs is an emergency. However, the absence of gluten, whose presence determines the overall appearance and textural properties of bread making goods, makes it a technological challenge.

This review presents various alternative materials, functional ingredients (added individually or in conjunction), and technologies, which can result in GFBs of desirable quality. In the future, further investigations and research should be focused on the discovery and application of more innovative gluten substitutes and the cultivation and commercialization of the coeliac-safe wheat. Research on combination of these approaches should be conducted to detect the potential synthetic effects and create GF products with properties equaling those of wheat breads.

\section{Acknowledgements}

This research was financially supported by Natural Science Foundatiom of Liaoning Province of China(No.2014020122).

\section{References}

Aguilar, N., Albanell, E., Miñarro, B., \& Capellas, M. (2016). Chestnut flour sourdough for gluten-free bread making. European Food Research and Technology, 242(10), 1-8. http://dx.doi.org/10.1007/ s00217-016-2679-z.

Aguilar, N., Albanell, E., Miñarro, B., Guamis, B., \& Capellas, M. (2015). Effect of tiger nut-derived products in gluten-free batter and bread. Food Science \& Technology International, 21(5), 323-331. PMid:24854294. http://dx.doi.org/10.1177/1082013214535615.

Alencar, N. M. M., Steel, C. J., Alvim, I. D., Morais, E. C. D., \& Bolini, H. M. A. (2015). Addition of quinoa and amaranth flour in gluten-free breads: Temporal profile and instrumental analysis. Lebensmittel-Wissenschaft + Technologie, 62(2), 1011-1018. http:// dx.doi.org/10.1016/j.lwt.2015.02.029.

Altenbach, S. B., Tanaka, C. K., \& Seabourn, B. W. (2014). Silencing of omega-5 gliadins in transgenic wheat eliminates a major source of environmental variability and improves dough mixing properties of flour. BMC Plant Biology, 14(1), 1-13. PMid:25539796. http:// dx.doi.org/10.1186/s12870-014-0393-1.

Aprodu, I., \& Banu, I. (2015). Influence of dietary fiber, water, and glucose oxidase on rheological and baking properties of maize based gluten-free bread. Food Science and Biotechnology, 24(4), 1301-1307. http://dx.doi.org/10.1007/s10068-015-0167-z.

Barro, F., Iehisa, J. C. M., Giménez, M. J., García-Molina, M. D., Ozuna, C. V., Comino, I., Sousa, C., \& Gil-Humanes, J. (2016). Targeting of prolamins by RNAi in bread wheat: effectiveness of seven silencingfragment combinations for obtaining lines devoid of coeliac disease epitopes from highly immunogenic gliadins. Plant Biotechnology Journal, 14(3), 986-996. PMid:26300126. http://dx.doi.org/10.1111/ pbi. 12455 .

Basso, F. M., Mangolim, C. S., Aguiar, M. F. A., Monteiro, A. R. G., Peralta, R. M., \& Matioli, G. (2015). Potential use of cyclodextringlycosyltransferase enzyme in bread-making and the development of gluten-free breads with pinion and corn flours. International Journal of Food Sciences and Nutrition, 66(3), 275-281. PMid:25666418. http://dx.doi.org/10.3109/09637486.2015.1007450. 
Becker, D., Folck, A., Knies, P., Lörz, H., \& Wieser, H. (2007). Silencing the a-gliadins inhexaploid bread wheat. In: G. L. Lookhart \& P. K. W. Ng (Eds.), Gluten proteins (pp. 86-89). Campinas: St Paul.

Becker, D., Wieser, H., Koehler, P., Folck, A., Mühling, K. H., \& Zörb, C. (2012). Protein composition and techno-functional properties of transgenic wheat with reduced $\alpha$-gliadin conten to btained by RNA interference. Journal of Applied Botany and Food Quality, 85(1), 23-33.

Campo, E., del Arco, L., Urtasun, L., Oria, R., \& Ferrer-Mairal, A. (2016). Impact of sourdough on sensory properties and consumers' preference of gluten-free breads enriched with teff flour. Journal of Cereal Science, 67, 75-82. http://dx.doi.org/10.1016/j.jcs.2015.09.010.

Capriles, V. D., \& Arêas, J. A. G. (2013). Effects of prebiotic inulin-type fructans on structure, quality, sensory acceptance and glycemic response of gluten-free breads. Food \& Function, 4(1), 104-110. PMid:23032642. http://dx.doi.org/10.1039/C2FO10283H.

Capriles, V. D., \& Arêas, J. A. G. (2014). Novel approaches in gluten-free breadmaking: interface between food science, nutrition and health. Comprehensive Reviews in Food Science and Food Safety, 13(5), 871890. http://dx.doi.org/10.1111/1541-4337.12091.

Catassi, C., \& Fasano, A. (2008). Celiac disease. In: E. K. Arendt \& F. Dal Bello (Eds.), Gluten-free cereals products and beverages (pp. 1-22). Campinas: MA.

Clerici, M. T. P. S., Airoldi, C., \& El-Dash, A. A. (2009). Production of acidic extruded rice flour and its influence on the qualities of gluten-free bread. Lebensmittel-Wissenschaft + Technologie, 42(2), 618-623. http://dx.doi.org/10.1016/j.lwt.2008.08.010.

De Vuyst, L., \& Vancanneyt, M. (2007). Biodiversity and identification of sourdough lactic acid bacteria. Food Microbiology, 24(2), 120127. PMid:17008154. http://dx.doi.org/10.1016/j.fm.2006.07.005.

Deora, N. S., Deswal, A., \& Mishra, H. N. (2015). Functionality of alternative protein in gluten-free product development. Food Science \& Technology International, 21(5), 364-379. PMid:26048849. http:// dx.doi.org/10.1177/1082013214538984.

Flander, L., Holopainen, U., Kruus, K., \& Buchert, J. (2011). Effects of tyrosinase and laccase on oat proteins and quality parameters of gluten-free oat breads. Journal of Agricultural and Food Chemistry, 59(15), 8385-8390. PMid:21732697. http://dx.doi.org/10.1021/ jf200872r.

Furlán, L. T. R., Padilla, A. P., \& Campderrós, M. E. (2015). Improvement of gluten-free bread properties by the incorporation of bovine plasma proteins and different saccharides into the matrix. Food Chemistry, 170, 257-264. PMid:25306343. http://dx.doi.org/10.1016/j. foodchem.2014.08.033.

Gil-Humanes, J., Pistón, F., Altamirano-Fortoul, R., Real, A., Comino, I., Sousa, A., Rosell, C. M., \& Barro, F. (2014). Reduced-gliadin wheat bread: an alternative to the gluten-free diet for consumers suffering gluten-related pathologies. PLoS One, 9(3), e90898. PMid:24621595. http://dx.doi.org/10.1371/journal.pone.0090898.

Gil-Humanes, J., Pistón, F., Shewry, P. R., Tosi, P., \& Barro, F. (2011). Suppression of gliadins results in altered protein body morphology in wheat. Journal of Experimental Botany, 62(12), 4203-4213. PMid:21561951. http://dx.doi.org/10.1093/jxb/err119.

Gil-Humanes, J., Pistón, F., Tollefsen, S., Sollid, L. M., \& Barro, F. (2010). Effective shut-down in the expression of celiac disease-related wheat gliadin T-cell epitopes by RNA interference. Proceedings of the National Academy of Sciences of the United States of America, 107(39), 17023-17028. PMid:20829492. http://dx.doi.org/10.1073/ pnas. 1007773107.

Gunness, P., \& Gidley, M. J. (2010). Mechanisms underlying the cholesterol-lowering properties of soluble dietary fibre polysaccharides.
Food \& Function, 1(2), 149-155. PMid:21776465. http://dx.doi. org/10.1039/c0fo00080a.

Hager, A. S., \& Arendt, E. K. (2013). Influence of hydroxypropylmethylcellulose (HPMC), xanthan gum and their combination on loaf specific volume, crumb hardness and crumb grain characteristics of gluten-free breads based on rice, maize, teff and buckwheat. Food Hydrocolloids, 32(1), 195-203. http://dx.doi.org/10.1016/j.foodhyd.2012.12.021.

Hager, A. S., Wolter, A., Czerny, M., Bez, J., Zannini, E., Arendt, E. K., \& Czerny, M. (2012a). Investigation of product quality, sensory profile and ultrastructure of breads made from a range of commercial gluten-free flours compared to their wheat counterparts. European Food Research and Technology, 235(2), 333-344. http://dx.doi. org/10.1007/s00217-012-1763-2.

Hager, A. S., Wolter, A., Jacob, F., Zannini, E., \& Arendt, E. K. (2012b). Nutritional properties and ultra-structure of commercial gluten free flours from different botanical sources compared to wheat flours. Journal of Cereal Science, 56(2), 239-247. http://dx.doi.org/10.1016/j. jcs.2012.06.005.

Hatta, E., Matsumoto, K., \& Honda, Y. (2015). Bacillolysin, papain, and subtilisin improve the quality of gluten-free rice bread. Journal of Cereal Science, 61, 41-47. http://dx.doi.org/10.1016/j.jcs.2014.10.004.

Heredia-Sandoval, N. G., Valencia-Tapia, M. Y., de la Barca, A. M. C., \& Islas-Rubio, A. R. (2016). Microbial Proteases in Baked Goods: Modification of Gluten and Effects on Immunogenicity and Product Quality. Foods, 5(3), 59-68. PMid:28231153. http://dx.doi. org/10.3390/foods5030059.

Hug-Iten, S., Echer, F., \& Conde-Petit, B. (2001). Structural properties of starch in bread and bread model systems:influence of an antistaling a-amylose. Cereal Chemistry, 78(4), 421-428. http://dx.doi.org/10.1094/ CCHEM.2001.78.4.421.

Kagnoff, M. F. (2005). Overview and pathogenesis of celiac disease. Gastroenterology, 128(4, Suppl 1), S10-S18. PMid:15825116. http:// dx.doi.org/10.1053/j.gastro.2005.02.008.

Korus, J., Juszczak, L., Ziobro, R., Witczak, M., Grzelak, K., \& Sójka, M. (2012). Defatter strawberry and blackcurrant seeds as functional ingredients of gluten-free bread. Journal of Texture Studies, 43(1), 29-39. http://dx.doi.org/10.1111/j.1745-4603.2011.00314.x.

Korus, J., Witczak, M., Ziobro, R., \& Juszczak, L. (2015). The influence of acorn flour on rheological properties of gluten-free dough and physical characteristics of the bread. European Food Research and Technology, 240(6), 1135-1143. http://dx.doi.org/10.1007/s00217015-2417-y.

Lamothe, L. M., Srichuwong, S., Reuhs, B. L., \& Hamaker, B. R. (2015). Quinoa (Chenopodium quinoa W.) and amaranth (Amaranthus caudatus L.) provide dietary fibres high in pectic substances and xyloglucans. Food Chemistry, 167, 490-496. PMid:25149016. http:// dx.doi.org/10.1016/j.foodchem.2014.07.022.

Lemos, A. R., Capriles, V.D., Pinto e Silva, M.E.M., \& Arêas, J.A.G. (2012). Effect of incorporation of amaranth on the physical properties and nutritional value of cheese bread. Food Science and Technology, 32(3), 427-431.

López-Tenorio, J. A., Rodríguez-Sandoval, E., \& Sepúlveda-Valencia, J. U. (2015). The Influence of Different Emulsifiers on the Physical and Textural Characteristics of Gluten-Free Cheese Bread. Journal of Texture Studies, 46(4), 227-239. http://dx.doi.org/10.1111/jtxs.12121.

Martínez, M. M., Díaz, Á., \& Gómez, M. (2014). Effect of different microstructural features of soluble and insoluble fibres on glutenfree dough rheology and bread-making. Journal of Food Engineering, 142, 49-56. http://dx.doi.org/10.1016/j.jfoodeng.2014.06.020. 
Mezaize, S., Chevallier, S., Le-Bail, A., \& de Lamballerie, M. (2010). Gluten-free frozen dough: influence of freezing on dough rheological properties and bread quality. Food Research International, 43(8), 2186-2192. http://dx.doi.org/10.1016/j.foodres.2010.07.030.

Michalcová, E., Potocká, E., Chmelová, D., \& Ondrejovič, M. (2012). Study of wheat protein degradation during germination. Journal of Microbiology Biotechnology \& Food Sciences, 1, 1439-1447.

Miñarro, B., Albanell, E., Aguilar, N., Guamis, B., \& Capellas, M. (2012). Effect of legume flours on baking characteristics of glutenfree bread. Journal of Cereal Science, 56(2), 476-481. http://dx.doi. org/10.1016/j.jcs.2012.04.012.

Mir, S. A., Shah, M. A., Naik, H. R., \& Zargar, I. A. (2016). Influence of hydrocolloids on dough handling and technological properties of gluten-free breads. Trends in Food Science \& Technology, 51, 49-51. http://dx.doi.org/10.1016/j.tifs.2016.03.005.

Mohammadi, M., Azizi, M. H., Neyestani, T. R., Hosseini, H., \& Mortazavian, A. M. (2015). Development of gluten-free bread using guar gum and transglutaminase. Journal of Industrial and Engineering Chemistry, 21(1), 398-1402.

Mohammadi, M., Sadeghnia, N., Azizi, M. H., Neyestani, T. R., \& Mortazavian, A. M. (2014). Development of gluten-free flat bread using hydrocolloids: Xanthan and CMC. Journal of Industrial and Engineering Chemistry, 20(4), 1812-1818. http://dx.doi.org/10.1016/j. jiec.2013.08.035.

Murray, J. A. (1999). The widening spectrum of celiac disease. American Society for Clinical Nutrition, 69(3), 354-365. PMid:10075317.

Mustalahti, K., Catassi, C., Reunanen, A., Fabiani, E., Heier, M., McMillan, S., Murray, L., Metzger, M. H., Gasparin, M., Bravi, E., \& Mäki, M., and the Coeliac EU Cluster, Project Epidemiology (2010). The prevalence of celiac disease in Europe: results of a centralized, international mass screening project. Annals of Medicine, 42(8), 587-595. PMid:21070098. http://dx.doi.org/10.3109/07853890.20 10.505931 .

Najafabadi, L. I., Le-Bail, A., Hamdami, N., Monteau, J. Y., \& Keramat, J. (2014). Impact of baking conditions and storage temperature on staling of fully and part-baked Sangak bread. Journal of Cereal Science, 60(1), 151-156. http://dx.doi.org/10.1016/j.jcs.2014.02.004.

Naji-Tabasi, S., \& Mohebbi, M. (2015). Evaluation of cress seed gum and xanthan gum effect on macrostructure properties of glutenfree bread by image processing. Journal of Food Measurement and Characterization, 9(1), 110-119. http://dx.doi.org/10.1007/ s11694-014-9216-1.

Nicolae, A., Radu, G. L., \& Belc, N. (2016). Effect of sodium carboxymethyl cellulose on gluten-free dough rheology. Journal of Food Engineering, 168, 16-19. http://dx.doi.org/10.1016/j.jfoodeng.2015.07.006.

Nozawa, M., Ito, S., \& Arai, E. (2016). Effect of ovalbumin on the quality of gluten-free rice flour bread made with soymilk. LebensmittelWissenschaft + Technologie, 66, 598-605. http://dx.doi.org/10.1016/j. lwt.2015.11.010.

O'Shea, N., Arendt, E., \& Gallagher, E. (2014). State of the Art in Gluten-Free Research. Journal of Food Science, 79(6), R1067-R1076. PMid:24784553. http://dx.doi.org/10.1111/1750-3841.12479.

O’Shea, N., Rößle, C., Arendt, E., \& Gallagher, E. (2015). Modelling the effects of orange pomace using response surface design for glutenfree bread baking. Food Chemistry, 166, 223-230. PMid:25053049. http://dx.doi.org/10.1016/j.foodchem.2014.05.157.

Onyango, C., Mutungi, C., Unbehend, G., \& Lindhauer, M. G. (2011). Modification of gluten-free sorghum batter and bread using maize, potato, cassava or rice starch. Lebensmittel-Wissenschaft + Technologie, 44(3), 681-686. http://dx.doi.org/10.1016/j.lwt.2010.09.006.
Palabiyik, I., Yildiz, O., Toker, O. S., Cavus, M., Ceylan, M. M., \& Yurt, B. (2016). Investigating the addition of enzymes in gluten-free flours-The effect on pasting and textural properties. LebensmittelWissenschaft + Technologie, 69, 633-641. http://dx.doi.org/10.1016/j. lwt.2016.01.019.

Pistón, F., Gil-Humanes, J., Rodríguez-Quijano, M., \& Barro, F. (2011). Down-regulating $\gamma$-gliadins in bread wheat leads to non-specific increases in other gluten proteins and has no major effect on dough gluten strength. PLoS One, 6(9), e24754. PMid:21935456. http:// dx.doi.org/10.1371/journal.pone.0024754.

Pongjaruvat, W., Methacanon, P., Seetapan, N., Fuongfuchat, A., \& Gamonpilas, C. (2014). Influence of pregelatinised tapioca starch and transglutaminase on dough rheology and quality of gluten-free jasmine rice breads. Food Hydrocolloids, 36(2), 143-150. http:// dx.doi.org/10.1016/j.foodhyd.2013.09.004.

Pszczola, D. E. (2012). The rise of gluten-free. Food Technology, 66, 55-66.

Renzetti, S., \& Rosell, C. M. (2016). Role of enzymes in improving the functionality of proteins in non-wheat dough systems. Journal of Cereal Science, 67, 35-45. http://dx.doi.org/10.1016/j.jcs.2015.09.008.

Rizzello, C. G., Curiel, J. A., Nionelli, L., Vincentini, O., Di Cagno, R., Silano, M., Gobbetti, M., \& Coda, R. (2014). Use of fungal proteases and selected sourdough lactic acid bacteria for making wheat bread with an intermediate content of gluten. Food Microbiology, 37(2), 59-68. PMid:24230474. http://dx.doi.org/10.1016/j.fm.2013.06.017.

Rocha Parra, A. F., Ribotta, P. D., \& Ferrero, C. (2015a). Starch-Apple Pomace Mixtures: Pasting Properties and Microstructure. Food and Bioprocess Technology, 8(9), 1854-1863. http://dx.doi.org/10.1007/ s11947-015-1541-9.

Rocha Parra, A. F., Ribotta, P. D., \& Ferrero, C. (2015b). Apple pomace in gluten-free formulations: effect on rheology and product quality. International Journal of Food Science \& Technology, 50(3), 682-690. http://dx.doi.org/10.1111/ijfs.12662.

Rosell, C. M., Barro, F., Sousa, C., \& Carmen Mena, M. (2014). Cereals for developing gluten-free products and analytical tools for gluten detection. Journal of Cereal Science, 59(3), 354-364. http://dx.doi. org/10.1016/j.jcs.2013.10.001

Różyło, R., Rudy, S., Krzykowski, A., \& Dziki, D. (2015a). Novel application of freeze-dried amaranth sourdough in gluten-free bread production. Journal of Food Process Engineering, 38(2), 135-143. http://dx.doi.org/10.1111/jfpe.12152.

Różyło, R., Rudy, S., Krzykowski, A., Dziki, D., Gawlik-Dziki, U., Różyło, K., \& Skonecki, S. (2015b). Effect of adding fresh and freeze-dried buckwheat sourdough on gluten-free bread quality. International Journal of Food Science \& Technology, 50(2), 313-322. http://dx.doi. org/10.1111/ijfs.12622.

Różyło, R., Rudy, S., Krzykowski, A., Dziki, D., Siastała, M., \& Polak, R. (2016). Gluten-free bread prepared with fresh and dried rice sourdough-texture and sensory evaluation. Journal of Texture Studies, 47(5), 443-453. http://dx.doi.org/10.1111/jtxs.12180.

Sabanis, D., \& Tzia, C. (2011). Effect of hydrocolloids on selected properties of gluten-free dough and bread. Food Science \& Technology International, 17(4), 279-291. PMid:21917639. http://dx.doi. org/10.1177/1082013210382350.

Sarawong, C., Gutiérrez, Z. R., Berghofer, E., \& Schoenlechner, R. (2014). Effect of green plantain flour addition to gluten-free bread on functional bread properties and resistant starch content. Journal of Food Science and Technology, 49(8), 1825-1833. http://dx.doi. org/10.1111/ijfs.12491. 
Sayed, H. S., Sakr, A. M., \& Hassan, N. M. M. (2016). Effect of Pseudo Cereal Flours on Technological, Chemical and Sensory Properties of Pan Bread. World Journal of Dairy \& Food Sciences, 11, 10-17.

Sciarini, L. S., Pérez, G. T., Lamballerie, M., León, A. E., \& Ribotta, P. D. (2012). Partial-baking process on gluten-free bread: impact of hydrocolloid addition. Food and Bioprocess Technology, 5(5), 17241732. http://dx.doi.org/10.1007/s11947-011-0529-3.

Stefańska, I., Piasecka-Jóźwiak, K., Kotyrba, D., Kolenda, M., \& Stecka, K. M. (2016). Selection of lactic acid bacteria strains for the hydrolysis of allergenic proteins of wheat flour. Journal of the Science of Food \& Agriculture, 96(11), 3897-3905.

Steffolani, E., Hera, E., Pérez, G., \& Gómez, M. (2014). Effect of chia (Salvia His-panica L) addition on the quality of gluten-free bread. Journal of Food Quality, 37(5), 309-317. http://dx.doi.org/10.1111/ jfq. 12098.

Therdthai, N., Tanvarakom, T., Ritthiruangdej, P., \& Zhou, W. (2016). Effect of microwave assisted baking on quality of rice flour bread. Journal of Food Quality, 39(4), 245-254. http://dx.doi.org/10.1111/ jfq. 12207.

Thompson, T. (2001). Wheat starch, gliadin, and the gluten-free diet. Journal of the American Dietetic Association, 101(12), 1456-1459. PMid:11762742. http://dx.doi.org/10.1016/S0002-8223(01)00351-0.

Tsatsaragkou, K., Gounaropoulos, G., \& Mandala, I. (2014). Development of gluten free bread containing carob flour and resistant starch. Lebensmittel-Wissenschaft + Technologie, 58(1), 124-129. http:// dx.doi.org/10.1016/j.lwt.2014.02.043.

Tsatsaragkou, K., Protonotariou, S., \& Mandala, I. (2016). Structural role of fibre addition to increase knowledge of non-gluten bread. Journal of Cereal Science, 67, 58-67. http://dx.doi.org/10.1016/j. jcs.2015.10.003.

Turkut, G. M., Cakmak, H., Kumcuoglu, S., \& Tavman, S. (2016). Effect of quinoa flour on gluten-free bread batter rheology and bread quality. Journal of Cereal Science, 69, 174-181. http://dx.doi. org/10.1016/j.jcs.2016.03.005.

Vallons, K. J. R., Ryan, L. A. M., \& Arendt, E. K. (2011). Promoting structure formation by high pressure in gluten-free flours.
Lebensmittel-Wissenschaft + Technologie, 44(7), 1672-1680. http:// dx.doi.org/10.1016/j.lwt.2010.11.024.

Villanueva, M., Mauro, R. R., Collar, C., \& Ronda, F. (2015). Acidification of protein-enriched rice starch doughs: effects on breadmaking. European Food Research and Technology, 240(4), 783-794. http:// dx.doi.org/10.1007/s00217-014-2384-8.

Watanabe, Y. (2011). Overview of Plant RNAi. In: J. M. Walker (Ed.), Methods in Molecular Biology (pp. 1-11). Campinas: New York.

Witczak, M., Ziobro, R., Juszczak, L., \& Korus, J. (2016). Starch and starch derivatives in gluten-free systems-A review. Journal of Cereal Science, 67, 46-57. http://dx.doi.org/10.1016/j.jcs.2015.07.007.

Wronkowska, M., Haros, M., \& Soral-Śmietana, M. (2013). Effect of starch substitution by buckwheat flour on gluten-free bread quality. Food and Bioprocess Technology, 6(7), 1820-1827. http://dx.doi. org/10.1007/s11947-012-0839-0.

Yano, H. (2010). Improvements in the bread-making quality of gluten-free rice batter by glutathione. Journal of Agricultural and Food Chemistry, 58(13), 7949-7954. PMid:20515077. http://dx.doi. org/10.1021/jf1003946.

Yano, H. (2012). Comparison of oxidized and reduced glutathione in the bread-making qualities of rice batter. Journal of Food Science, 77(2), C182-C188. PMid:22309461. http://dx.doi.org/10.1111/j.17503841.2011.02556.x.

Zannini, E., Jones, J. M., Renzetti, S., \& Arendt, E. K. (2012). Functional Replacements for Gluten. Annual Review of Food Science and Technology, 3(3), 227-245. PMid:22385166. http://dx.doi.org/10.1146/ annurev-food-022811-101203.

Ziobro, R., Juszczak, L., Witczak, M., \& Korus, J. (2016). Non-gluten proteins as structure forming agents in gluten free bread. Journal of Food Science and Technology, 53(1), 571-580. PMid:26787976. http://dx.doi.org/10.1007/s13197-015-2043-5.

Ziobro, R., Korus, J., Juszczak, L., \& Witczak, T. (2013). Influence of inulin on physical characteristics and staling rate of gluten-free bread. Journal of Food Engineering, 116(1), 21-27. http://dx.doi. org/10.1016/j.jfoodeng.2012.10.049. 